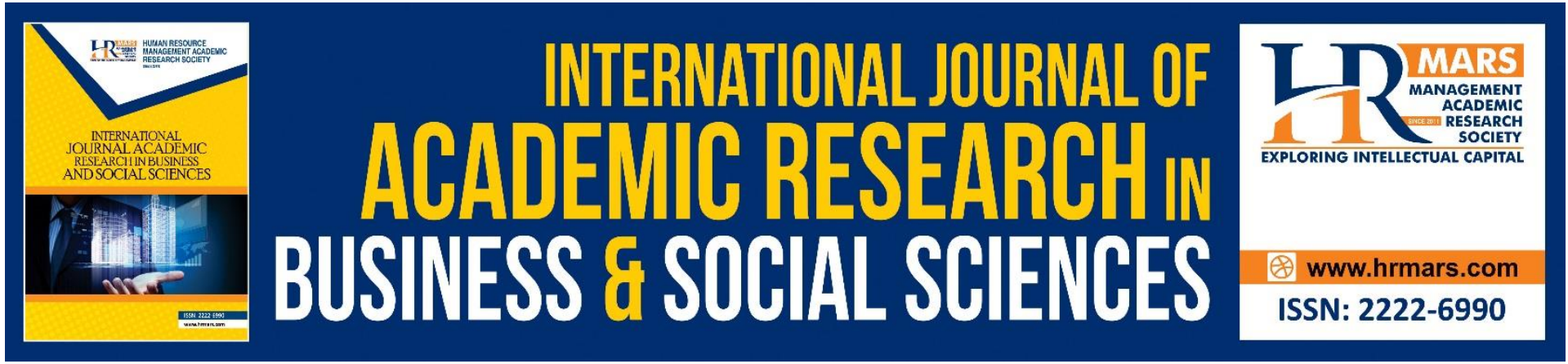

\title{
The Financial Technology (M-Banking) Adoption Among Baby-Boomers in Twenty-First Century
}

Nor Hazanah Miskan, Nurul Liyana Hussin, Nurulhayah Muhamad, Maryam Mohd Esa, Noorizda Emillia Mohd Aziz

To Link this Article: http://dx.doi.org/10.6007/IJARBSS/v11-i8/10703

DOI:10.6007/IJARBSS/v11-i8/10703

Received: 05 June 2021, Revised: 10 July 2021, Accepted: 04 August 2021

Published Online: 23 August 2021

In-Text Citation: (Miskan et al., 2021)

To Cite this Article: Miskan, N. H., Hussin, N. L., Muhamad, N., Esa, M. M., \& Aziz, N. E. M. (2021). The Financial Technology (M-Banking) Adoption Among Baby-Boomers in Twenty-First Century. International Journal of Academic Research in Business and Social Sciences, 11(8), 1579-1583.

Copyright: (c) 2021 The Author(s)

Published by Human Resource Management Academic Research Society (www.hrmars.com)

This article is published under the Creative Commons Attribution (CC BY 4.0) license. Anyone may reproduce, distribute, translate and create derivative works of this article (for both commercial and non-commercial purposes), subject to full attribution to the original publication and authors. The full terms of this license may be seen at: http://creativecommons.org/licences/by/4.0/legalcode

Vol. 11, No. 8, 2021, Pg. 1579 - 1583

http://hrmars.com/index.php/pages/detail/IJARBSS

JOURNAL HOMEPAGE

Full Terms \& Conditions of access and use can be found at http://hrmars.com/index.php/pages/detail/publication-ethics 


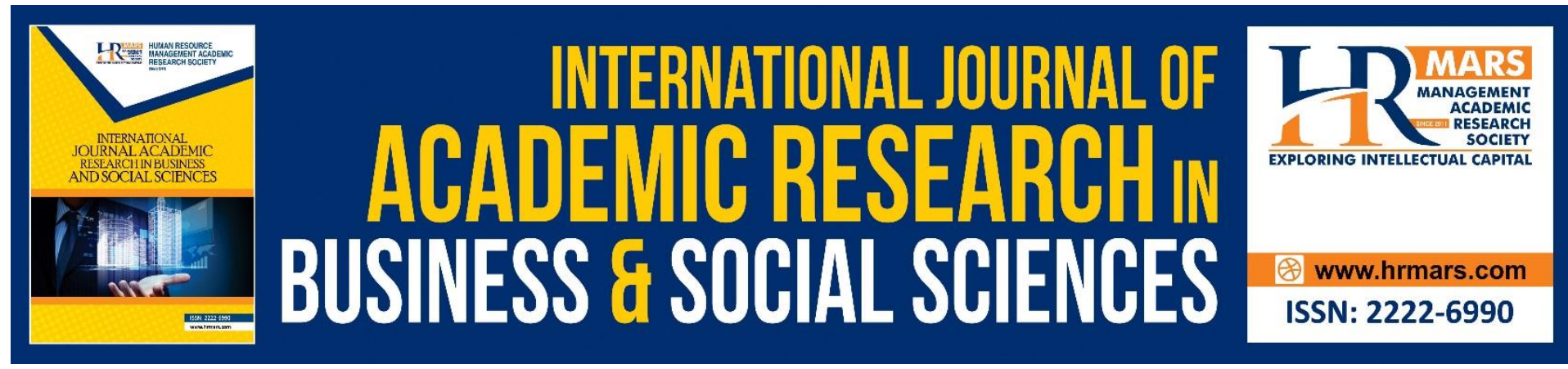

\title{
The Financial Technology (M-Banking) Adoption Among Baby-Boomers in Twenty-First Century
}

\author{
Nor Hazanah Miskan, Nurul Liyana Hussin, Nurulhayah \\ Muhamad, Maryam Mohd Esa, Noorizda Emillia Mohd Aziz \\ Faculty of Business Innovation and Technology Kolej Universiti Islam Melaka Melaka
}

\begin{abstract}
This study seeks to examine the level of acceptance of financial technology ( $m$-banking) among baby- boomers in Melaka. A self-administered questionnaire was completed online by 73 respondents (aged 55 years or more) who use their mobile devices to conduct banking activities. Results confirm that perceived ease of use, perceived usefulness and risk are the main elements influencing baby-boomers behavioural intention to use mobile banking services in Melaka. As a result, incorporating user experience as a value-adding differentiator is critical for increasing customer satisfaction and loyalty besides to widen the usage of mobile banking among old generation. In addition, the security is a top priority. Redoing the study in a post- COVID context would also be an interesting avenue of research. The ageing market is important for banks. This study highlights, in an m-banking context, which dimension of experience to focus on in order to improve level of using the mobile banking. This study also has supplied significant insights and information to banks, service providers, and software engineers in order to increase consumers' willingness to utilise mobile banking services in the future. After all, it can be described that the demographic factors can influence the acceptance and the usage of mobile banking includes age, race, networking, style of living and level of education where this study has not been thoroughly investigated. Lee (2009) descried that some demographic factor interrelate that may have an impact on mobile banking adoption. This study is the first to consider mobile service experience of elderly individuals as well as the impact of each of the experience dimensions on an important dependent variable, acceptance. By considering the perceived ease of use, perceived usefulness and risk as independent variable. this study also provides an in-depth examination of these variable towards the dependent variable.
\end{abstract}

Keywords Financial Technology, Baby-boomers, Acceptance, Financial Market

\section{Introduction}

This study will focus on financial technology acceptance among baby-boomers. Firstly, financial technology is a combination of technology and finance which nowadays broadly applied in our financial sector. Marc Hochstein (2015) defined financial technology or "FinTech" as the usage of technology in delivering financial solutions. Generally, the objective of FinTech is to attract customers with more efficient, user-friendly and automated various products and services. It can be described when the traditional banks have beat the 
improvements along with these line (Mackenzie, 2015) parallel with the technology advancement. The Financial Stability Board defines FinTech as "technologically enabled financial innovation that could result in new business models, applications, processes or products with an associated material effect on financial markets and institutions and the provision of financial services." Financial services are still primarily distributed through oldstyle channels. FinTech only plays a significant role in certain segments of the financial sector, such as retail payments, asset management and small loans. However, it is rapidly expanding into sectors such as lending-based crowd funding and chat box customer relations services. The use of technologies such as Al, Big Data and distributed ledgers (DLT) is also on the rise (Panetta, 2018).

\section{Financial Technology (FinTech) in Malaysia}

According to Rahim, Jaaffar, Sarkawi et al (2021), historically in Malaysia, the use of credit card was a Fintech development in the 1950s to help Malaysians minimize the burden in carrying cash all the time. The aim of financial technology in the 1990s was to encourage bank customers to use the online banking system instead of only automated teller machine. Fintech services are swiftly interrupting banks' services globally. Similarly, Malaysia's banking sector is experiencing the interruption since as more Fintech organizations are innovating new Fintech service to improve convenience for clienteles. Numerous regulatory agencies in Malaysia and the Malaysian government have set up several initiatives to encourage and provide a vigorous growth in the Malaysian Fintech and digital asset regulatory environment.

Ab Razak, Dali, \& Manaf (2019), also mentioned that driven by the Fourth Industrial Revolution force, the wave of FinTech has swept across the whole universe including Malaysia. Nowadays, more people begin to believe that FinTech could offer all- time solution for financial problems. As Malaysia is leading the world of Islamic finance, it is the best time to embrace this technology in catching up the worldwide competition.

Numerous sectors such as insurance, e-commerce payment, and logistics have incorporated Fintech in their businesses (Lim, Kim, Hur, \& Park, 2019). The increase in the utilization of Fintech was prompted due to the significant change in the financial system (Tasca, Aste, Pelizzon, \& Perony, 2016).

In addition, report by Fintech News Malaysia 2021, stated that Malaysia's digital shift has been ongoing for the past decade but the pandemic has accelerated digital banking adoption, the report says. In 2020, online and mobile banking penetration reached $112.5 \%$ and $61.8 \%$ respectively, and RM 460 million worth of mobile banking transactions were conducted - a $125 \%$ jump compared to the previous year. Other than that, The Malaysian government's Movement Control Order (MCO) acted as a catalyst, helping to add 3 million new mobile banking service subscribers last year as well as pushed e-wallet usage and adoption to new highs.

Merchants were quick to embrace the trend, with over 400,000 new businesses registering for QR code payment acceptance, a 164\% jump from the previous year. With the presence of Fin Tech in Malaysia, has shown consumers have accepted internet banking practices as part of their daily activities and the percentage is increasing from time to time. In other hand, web - based banking and electronic payments have demonstrated the efficiency of Malaysian 
technology and banking institutions are able to improve services according to the needs of their customers who are receptive to these new technology products. In addition, with the rise of FinTech in Malaysia, web -based banking and internet payments will gain a market edge and consistently be able to meet the needs and wants of their customers.

Figure1: Mobile BankingTransaction Value and Growth Rate

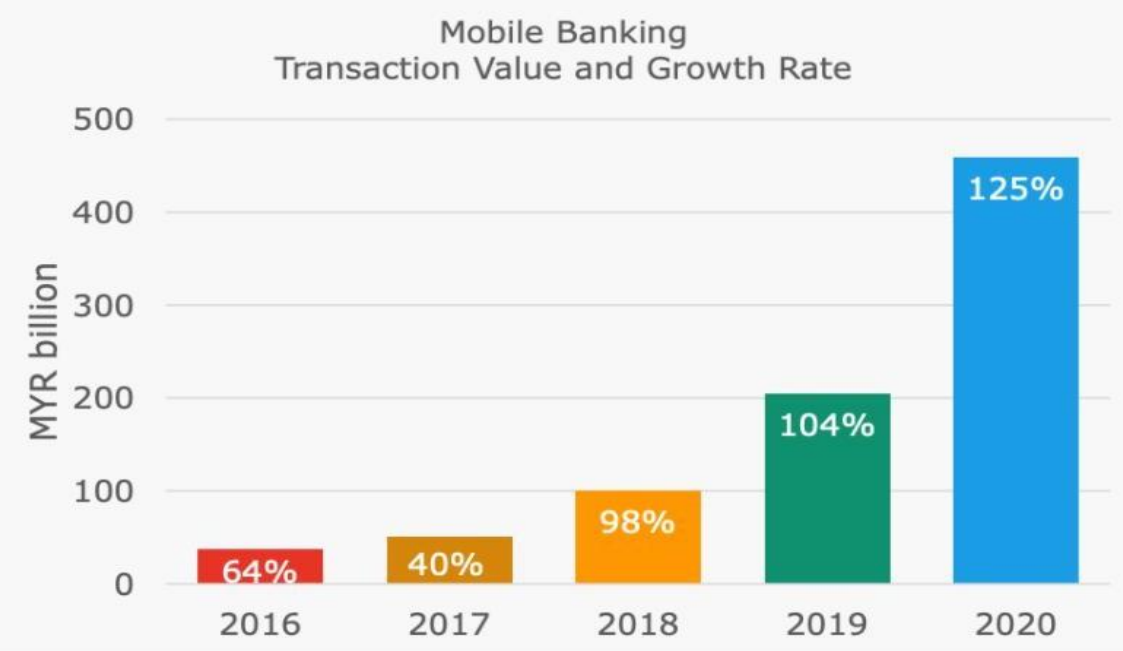

Fintech is a dynamic and innovative field that fully benefits from advances in information and communication technology (Barbu et al., 2021). The twenty-first century has witnessed important digitization such as payment applications, mobile wallet, crowdfunding platforms, and robo-advisors for wealth management (Huei et al., 2018). The recurrent development of Fintech mobile application proves Fintech's consistent innovation (Alwi et al., 2019).Fintech offers new prospects by improving transparency, minimizing costs, eradicating the use of intermediaries, and increasing the accessibility of information (Zavolokina, Dolata, \& Schwabe, 2016). Fintech organizations are extending their business scope into mobile platforms (e.g., mobile payment, mobile remittance). Traditional banking institutions are also evolving to offer innovative and differentiated financial services (Ryu, 2018).

Based on report by Fintech News Malaysia 2021, this builds on a rapidly maturing e-wallet industry which counts over 40 non-bank providers among which Touch 'n Go, Malaysia's biggest e-wallet with 5 million users and 300,000 merchants, Boost which serves some 8.8 million users and over 231,000 merchants, and BigPay which boasts 1.4 million users. In addition mentioned that on average, a a person in Malaysia made 170 e-payment transactions as compared to 150 in 2019. In year 2020, saw numerous regulatory changes being introduced to help digital finance thrive. In June, Bank Negara Malaysia (BNM) issued a new policy framework on electronic know-your-customer (eKYC) to facilitate digital onboarding. In tandem, the government has been working on a National Digital Identity Framework since 2019. 
Figure 2: E-Payment transactions Comparison

\section{On average, a person in Malaysla made 170 e-payment transactions as compared to 150 in 2019}

Online banking

transaction volume

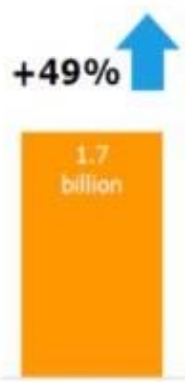

2019

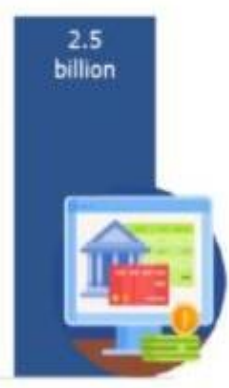

2020
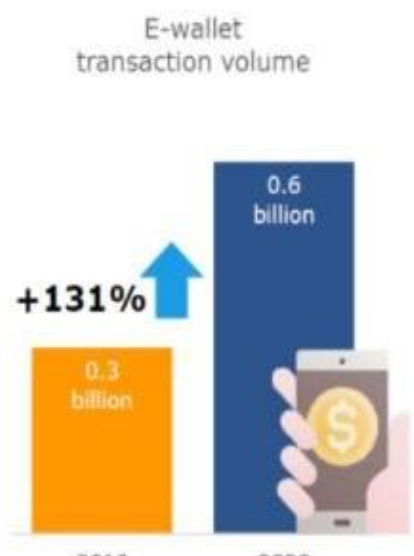

2019 transaction volume

2020
Merchant registrations for QR code acceptance

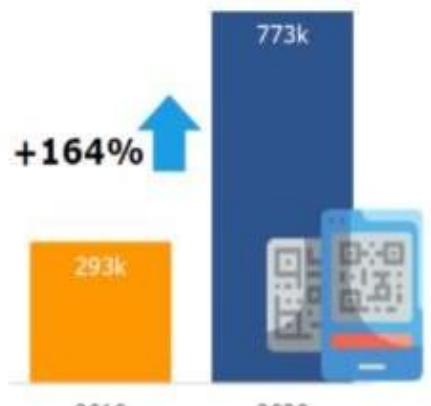

2019

Other than that, Krasnyuk, Tkalenko, \& Krasniuk (2021), mentioned that, FinTech companies are making investments more democratic, enabling free capital flows, driving change, providing comprehensive financial services that are more accessible to more people, better serving the day-to-day needs of people, and responding to a new generation of investors. Again, this researcher stated that, FinTech is a strong trend and a new vision in the field of financial services. Modern innovative technologies have significant potential to transform such a market and improve the quality of financial institutions' services to their customers. (Krasnyuk, Tkalenko, \& Krasniuk, 2021)

Based on Consumer International Report (2017) the Millennials in United States are the largest generation and the first to grow up digital where three times more likely than baby boomers in using mobile devices in banking. The research on the expectations of Millennials' in the USA indicates that a third believe that they would not need a bank in five years time and that half are 'counting on' tech start-ups to overhaul banks.

In 2015, Millennials outpaced Boomers, as the generation continues to grow due, in part, toan influx of young immigrants. Because of their renowned openness to new forms of technology, Millennials are usually the target market of FinTech startups and have begun to gain the attention of larger institutions as well (Augustine, 2017).

When considering spending power, boomers have the edge over Millennials; Americans over the age of 50 have the highest net worth of any other population segment. The prospects for future spending also look bright; over the next 20 years, spending by those over 50 years of age is expected to increase by $58 \%$ to $\$ 4.74$ trillion vs. growth of $24 \%$ to $\$ 3.53$ trillion for those 25-50 years old (Holtzman, 2013). Baby boomers refer to those born between 1946 and 1964 and have grown up and now are on the way to becoming ageing boomers. In Malaysia, the number of people aged 65 years and over has increased steadily since the 1970 s, and it is projected the number will triple from 2.0 million today to more than 6.0 million by 2040 (Haub, 2017). 
Figure 3: Smartphone Activities by Age

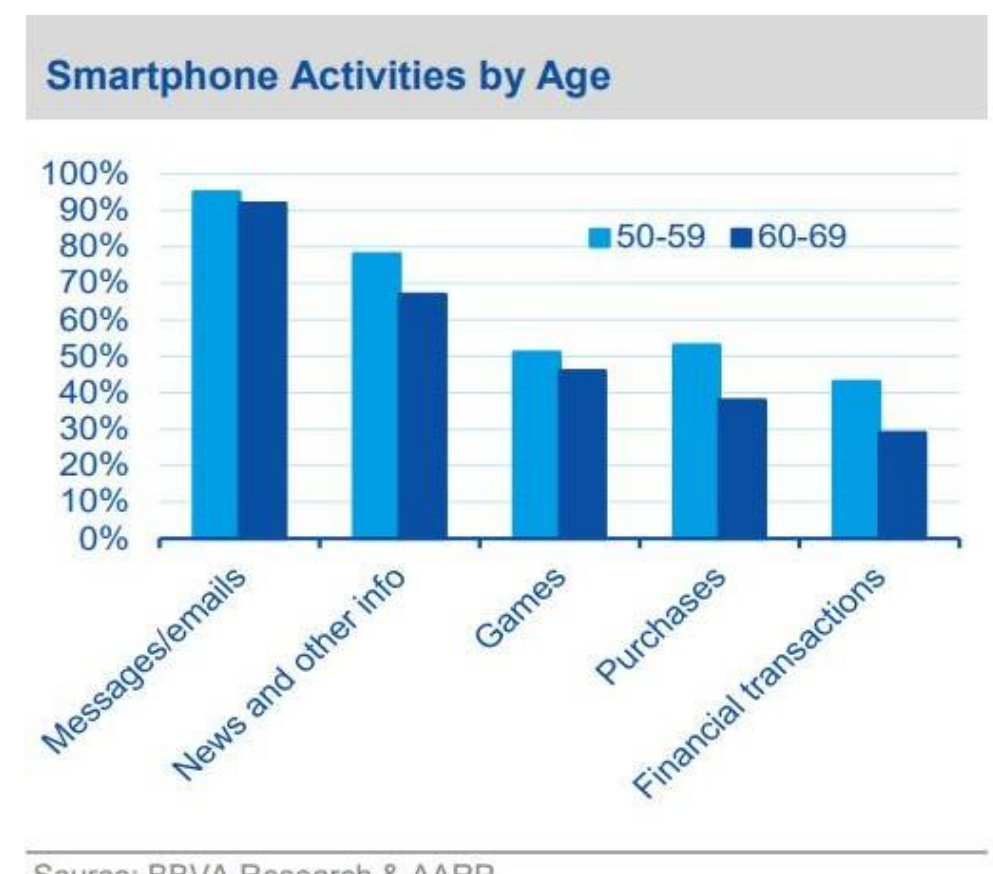

Source: BBVA Research \& AARP

Based on Figure 1, it can be described that the baby boomers of 50-59 years old own a smartphone and did various of activities such as reading the news, playing games and making purchased. However, for 60-69 years olds own smartphone and they are less likely to turn toit for the activities listed above (Anderson, 2016).

As with all opportunities for progress, the technological revolution raises new issues and may expose customers to little known risks. Two issues deserve close scrutiny by the public authorities are cyber risk and regulation.

Cyber risk can cause enormous damages. In 2017, the spread of two pieces of malicious software called WannaCry and NotPetya led to losses in the hundreds of millions of dollars for their high-profile victims, which include the British National Health Service and shipping giant Moller-Maersk of Denmark. Attacks through the interbank messaging service SWIFT resulted in large-scale theft from customers, including central banks, between 2016 and 2017. Illegal access to confidential emails was a key issue in the U.S. presidential campaign of 2016.

The consequences of these events, while serious, are still benign compared with what would happen in the event of a truly systemic cyber crisis: the British insurer Lloyd's and the American Big Data firm Cyence have estimated that a massive disruption to cloud computing services could cost the global economy more than $\$ 50 \mathrm{bn} .10$ The financial sector is highly exposed to cyber attacks because it makes intensive use of ICT, and because it is highly interconnected at the global level. It is attractive not only to digital thieves but also to politically motivated actors who want to disrupt the functioning of our economies. For these reasons, it was one of the first civilian sectors to enforce strict cybersecurity standards, and perhaps the only one that has achieved significant results in broad-based international cooperation. 
The growing numbers of fintech services offering mobile and cloud-based payments are failing to convert older users. One study from Canada found Generation X-ers are over twice as likely to try a digital payments solution as baby boomers.

Financial comparison website Ratehub.ca surveyed 1,000 Canadians about their use of financial services technology for its 2017 Digital Money Trends report. As reported by ITBusiness.ca, the survey reveals a growing divide between older banking customers and their millennial counterparts.

Younger users are far more likely to be interested in new payment solutions. The study found millennials are the most likely to use mobile and contactless payments as their "preferred" option for purchasing goods. They're also closer to adopting emerging services, such as Alassisted support bots. 44 percent of millennials said they'd trust a robo-advisor, compared with 23 percent of baby boomers.

\section{Literature Review}

Mobile banking Trend in 202: The 2021 has shown a change in living norms due to the Covid 19 pandemic that hit the world starting at the end of 2019. These new norms include day -to - day affairs and highly online -focused business methods. Thus, mobile banking has become a necessity to the community to facilitate financial transactions made anywhere and anytime. For example, the people in Tanzania can pay their bus fare via text messages if they are travelling for life-saving surgery. Safety was rated as the most in-demand mobile banking feature by consumers who use mobile banking. Consumers want their banking information to be safe, which is why $47 \%$ of Mobile Banking Competitive Edge Study respondents classified the ability to temporarily disable a payment card as "highly valuable." Given the strong demand for security features, many banks have yet to respond to these concerns with security and control services, giving those that do the opportunity to attract future bank switchers. Mobile banking is an extension of online banking that improves technology's capacity to help customers at their preferred time and location. The experience and maturity required to function within the complicated ecosystem are major hurdles in mobile banking. There are a variety of reasons or obstacles that prevent people from using mobile banking, and one of the most well-known is the security matter. The risk of a user's account information being compromised and used in a way that causes tangible or intangible harm or loss to the account holder is known as security risk. Unsecured networks, mobile viruses, third-party applications, and dangerous client behaviour are all threats to mobile banking (Kiran et. al, 2014).

Technology Acceptance Model (TAM): There are several models existing that have been used to investigate adoption of technology. Several studies focusing on adoption of mobile services have their roots in Technology Acceptance Model (TAM) originally proposed by Davies in 1986. The model is originally designed to predict user's acceptance of Information Technology and usage in an organizational context. TAM focuses on the attitude explanations of intention to use a specific technology or service; it has become a widely applied model for user acceptance and usage. Since its first appearance in literature more than 30 years ago, TAM has been continually deployed, updated, or coupled with different models in a wide range of settings and types of information systems. TAM was used to adapt the mobile banking components of Perceived Usefulness (PU), Perceived Ease of Use (PEOU), 
and Attitude towards Adoption (ATA). These constructs have also been used to analyse the uptake of mobile services, with results that are fairly consistent with TAM findings. TAM suggests that a users acceptance of information system is determined by that users intentionto use the systems, while perceived usefulness and ease of use can predict the usage intention, and perceived ease of use is hypothesized as a predictor of perceived usefulness. Accordingto TRA, users' belief influence their attitude, which in turn influence behavioural intention. Both perceived usefulness and perceived ease of use are beliefs. Thus, they will affect user's attitude. In addition, TAM states that perceived ease of use will have a direct effect on perceived usefulness.

Davis (1989) referred to PU as the extent to which an individual believes that using a system would improve his or her job performance. The validity and reliability of PU as a factor of intention to use information technology was established by Davis et al. (1989). PU in using Fintech service is defined as various performances or efficacy is achieved with the use of Fintech services (Lim et al., 2019). Davis (1989) outlined PEU as "the degree to which a person believes that use of a particular system would be free of effort, i.e., easy to comprehend or use" (Jen \& Hung, 2010). It is an important construct in information systems studies (Bilgihan et al., 2016; Foroughi et al., 2019). It is connectedto users' evaluation of the effort involved in the progression of using a technology (Venkatesh, 2000). PEU positively influences the intention to utilize smartphone apps (Okumus \& Bilgihan, 2014).

In this context, the current study aims to gain a better understanding of people's behavioural intentions and beliefs when it comes to mobile banking. The Technology Acceptance Model (TAM) (Davis et al, 1989) offered the framework for investigating customers' intentions to use mobile banking as well as the factors that influence their decision.

Figure 2: Research Framework

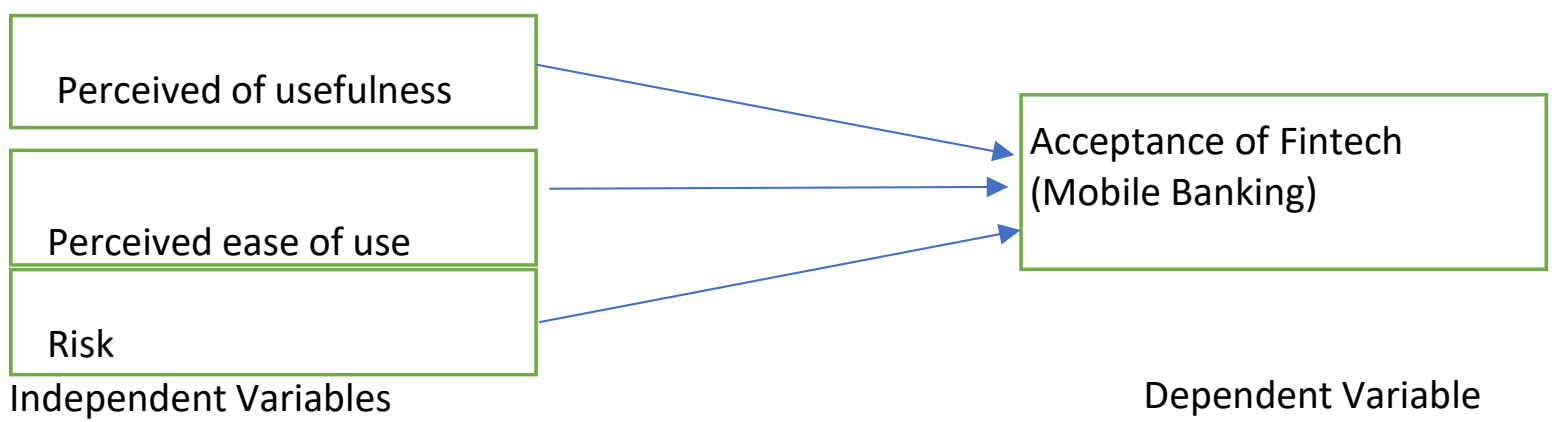

\section{Methodology}

This financial technology (M-Banking) adoption among baby-boomers in twenty-first century is a quantitative research. The purpose of this research is to obtain information from baby-boomers in Melaka. Thus, 73 baby boomers were surveyed using purposive sampling method. Respondents were given questionnaire to fill out and it was completely voluntary and private exercise. Five-point scale were used to assess the items and the items were adapted from variety of sources. 


\section{Findings}

Level of Mobile Banking Usage

The results of the study on the level of mobile banking usage are shown in Table 1 . The results showed that 47.9 percent or 34 respondents felt a moderate level of mobile banking usage. Meanwhile, a total of 27 respondents or 38 percent thought that the level of their mobile banking usage was high. While only 10 respondents felt the low level of mobile banking usage. Job descriptions were measured using five answer scale options from "strongly disagree" to "strongly agree". The results of the study found that on average, the respondents' scores for this study were at a moderate level $(M=3.36, S P=0.828)$.

Table 1: Distribution of respondents according to the level of mobile banking usage

\begin{tabular}{lllll}
\hline & Frequency & Percentage & Mean & $\begin{array}{l}\text { Standard } \\
\text { Deviation }\end{array}$ \\
\hline Description & & & 3.36 & .828 \\
Low $(1.00-2.33)$ & 10 & 14.1 & & \\
Moderate $(2.34-3.67)$ & 34 & 47.9 & & \\
High $(3.68-5.00)$ & 27 & 38.0 & & \\
Total & 71 & 100.0 & & \\
\hline
\end{tabular}

Table 2 showed the relationship between the variables studied which is the relationship between usefulness, ease of use, risks and usage of mobile banking. The results of this study show that there are only two independent variables are in moderate relationship strength according to the relationship strength table of Albert and Davis (1971) while there is one variable that has no significant relationship.

The results showed that there was a significant positive relationship between ease of use and adoption of mobile banking $(r=0.698, p<0.01)$. Based on the strength of the relationship of Albert and Davis (1971), the relationship between ease of use and adoption of mobile banking is a modest correlation. The positive correlation indicates that there is a positive relationship that the higher the degree of ease of use, the higher the level of use of mobile banking.

There was a significant positive relationship between usefulness and adoption of mobile banking supported by correlation coefficient $(r=0.687, p<0.01)$. Based on the strength of the Albert and Davis (1971) relationship, the relationship between the usefulness and adoption of mobile banking is a modest correlation. The positive correlation indicates that there is a positive correlation that the higher the degree of usefulness obtained during the adoption of mobile banking, the higher the level of use.

Table 2: Correlation of Variables and Adoption of Mobile Banking

\begin{tabular}{lll}
\hline Variables & $\mathrm{r}$ & $\mathrm{p}$ \\
\hline Ease of Use & $.698^{* *}$ & 0.000 \\
Uselfulness & $.687^{* *}$ & 0.000 \\
Risk & .190 & 0.112 \\
\hline
\end{tabular}

Multiple Regression Analysis 
Multiple regression analysis was used to test the impact of ease of use, usefulness and riskson the adoption of mobile banking. Regression analysis is a method that allows us to study relationships based on linear equations not only between one variable with one other variable but also between one variable with several variables (Hair et al., 2010).

Table 3: Multiple Regression Analysis

\begin{tabular}{|c|c|c|c|c|c|}
\hline $\begin{array}{l}\text { Dependent } \\
\text { Variable }\end{array}$ & Independent Variables & $\beta$ & BETA & $\mathrm{t}$ & Sig. \\
\hline & Constant & .433 & & 1.013 & .315 \\
\hline Adoption of & Ease of Use (X1) & .349 & .434 & 3.884 & .000 \\
\hline Mobile & Uselfulness (X2) & .322 & .366 & 3.247 & .002 \\
\hline Banking $(\mathrm{Y})$ & Risk (X3) & .173 & .113 & 1.410 & .163 \\
\hline $\mathrm{R} 2$ & .576 & & & & \\
\hline $\mathrm{F}$ & 30.384 & & & & \\
\hline Sig $\mathrm{F}$ & 0.000 & & & & \\
\hline
\end{tabular}

The results of the study shown in Table 3 show that $57.6 \%$ (R2 $=0.576)$ ease of use, usefulness and risk factors influence the adoption of mobile banking. Table 3 also shows that the Fstatistic $(F=30.384)$ was very large and a significant $p$ value $(0.000)$ or smaller than the alpha value of 0.01 . This indicates that the liner regression line slope of this model is estimated not to be equal to zero confirming that the study data correspond to the three linear regression prediction models proposed in this study. Referring to the regression analysis, mobile banking usage $(\mathrm{Y})$ is only influenced by two variables namely ease of use factor (X1) and usefulness (X2), yet risk (X3) has no significant relationship and does not contribute to mobile banking usage. Based on the results of this study as well, the relationship between the use of mobile banking $(Y)$ is influenced by ease of use factors $(X 1)$ and uselfulness (X2), can be explained using regression analysis expressed through linear equations as follows:

$$
\mathrm{Y}=0.433+0.349(\mathrm{X} 1)+0.322(\mathrm{X} 2)
$$

The results of this study show that if one unit of usefulness (X1) increases, then the level of mobile banking usage also increases by 0.349 . While one ease of use (X2) increased, so did the level of mobile banking usage also increased by 0.322 . While for this study, risk (X3) does not contribute to the use of mobile banking. The results of this study simultaneously support that convenience $(\mathrm{X} 1)$ and benefits $(\mathrm{X} 2)$ can influence the use of mobile banking.

\section{Discussion}

This discussion is based on the findings and objectives of the study that have been stated in Chapter One. The main objective of the study is to identify the level of usage of mobile banking among baby boomers in Melaka. The results of the study on the level of mobile banking usage are shown in Table 1 . The results showed that almost $50 \%$ of respondents felta moderate level of mobile banking usage. Otherwise, the results of the study found that on average, the respondents' scores for this study were at a moderate level $(M=3.36, S P=$ $0.828)$. Referring to the regression analysis, mobile banking usage $(Y)$ is only influenced by two variables namely usefulness factor $(X 1)$ and ease of use $(X 2)$, yet risk (X3) has no 
significant relationship and does not contribute to mobile banking usage. It can be concluded that the model used in this study can be accepted.

\section{Conclusion}

The aim of this research was to identify the acceptance of mobile banking usage among babyboomers in Melaka. The Technology Acceptance Model (TAM) suggest perceived ease of use and perceived usefulness attributes to be the powerful indicators to measure any technology adoption. According to our research framework, the modified model of Technology Acceptance Model (TAM) was implemented with adopting the elements of risk as one of independent variable. Based on the findings, although risk does not contribute to the use of mobile banking but the other side it shows that the level of security of mobile banking in Malaysia is stable and acceptable. With more digital transactions taking place improved security has also become a high priority. The new app has new data protection technology and biometric authentication for logins, such as fingerprint scanners and Face ID, to ensure that user information is never compromised.

In addition, the positive correlation of degree of ease will lead the higher level of use of mobile banking. More specific, there is a growing change in how Boomers engage with technologies due to mobile devices with respect boomers in Malaysian's community. In other perspective, it shows that Malaysia's networking becomes more reliable. Based on Malaysia Digital Economy Corporation (MDEC), Malaysia has started the process of integrating digital technologies into all areas of its economy and the next step is to carve its position as the "Heart of Digital Asean". Specifically, Malaysia will serve as a regional digital powerhouse launching global champions to lead the Fourth Industrial Revolution (Industry 4.0). In order to make it true, the banking industry need to constantly improve information access facilities or provide a simpler website display to ensure increased use of mobile banking from this group. When considering spending power, if the baby boomers who have the highest net worth are able to dominate the use of mobile banking then more online purchases will occur and further intensify the business and economy.

Thus, this financial technology ( $\mathrm{m}$-banking) adoption among baby-boomers in $21^{\text {st }}$ Century research shown the growing reliance on mobile banking, banks and financial institutions must rethink and re-evaluate their mobile banking strategies from time to time. Although generations and chronological age are powerful segmentation variables, it might be interesting to consider perceived age. This research is useful to know the consumer acceptance of mobile banking specifically among baby boomers in Malaysia environment and hopefully this research can support other researcher in doing the same topics in the future through in-depth observation with new and widen population.

\section{Acknowledgement}

This researcher would like to thank the Kolej Universiti Islam Melaka, for the opportunities given run this study.

\section{Corresponding Author}

Nor Hazanah Miskan

Kolej Universiti Islam Melaka Malaysia

Email: norhazanah@kuim.edu.my 


\section{References}

Ab Razak, M. I., Dali, M. N. A., \& Abdull Manaf, A. W. (2019). Embracing New World Of Islamic Fintech In Malaysia: Moving Towards Digitalisation. Era 9th International Economics and Business Management Conference

Alwi, S., Alpandi, R.M., Salleh, M. N. M., Basir, I. N., \& Md. Ariff, F. (2019). An empirical study on the customers' satisfaction on Fintech mobile payment services in Malaysia. International Journal of Advanced Science and Technology, 28(16), 390-400.

Barbu, C. M., Florea, D. L., Dabija, D. C., \& Barbu, M. C. R. (2021). Customer Experiencein Fintech. Journal of Theoretical and Applied Electronic Commerce Research, 16(5), 14151433.

Davis, F. D. (1989). Perceived usefulness, perceived ease of use, and user acceptance of information technology. MIS Quarterly, 13(3), 319-340.

Fintech Malaysia Report. (2021) - Fintech Reaches an Inflection Point in Malaysia https://fintechnews.my/27070/malaysia/fintech-malaysia-report-2021/.

Fishbein, M., \& Ajzen, I. (1975), Belief, Attitude, Intention and Behavior: An Introduction to Theory and Research, Addison-Wesley, Reading, MA

Foroughi, B., Iranmanesh, M., \& Hyun, S. S. (2019). Understanding the determinants of mobile banking continuance usage intention. Journal of Enterprise Information Management, 32(6), 1-19.

Foroughi, B., Shah, M. K. A., Ramayah, T., and Iranmanesh, M. (2019), "The effects of peripheral service quality on spectators' emotions and behavioural intentions", International Journal of Sports Marketing and Sponsorship, pp. 1-21.

Huei, C. T., Cheng, L. S., Seong, L. C., Khin, A. A., \& Bin, R. L. L. (2018). Preliminary study on consumer attitude towards FinTech products and services in Malaysia. International Journal of Engineering \& Technology, 7(2.29), 166-169.

Jen, W. Y., \& Hung, M. C. (2010). An empirical study of adopting mobile healthcare service: The family's perspective on the healthcare needs of their elderly members. Telemedicine and e-Health, 16(1), 41-48.

Kiran, K. V. D., Srivatsava, M. V. R., \& Devi, K. G. (2014). Risk Management in Mobile Banking. International Journal of Engineering Research\& Technology (IJERT), 3(3), 2278- 0181.

Krasnyuk, M., Tkalenko, A., \& Krasniuk, S. (2021). Development of the Fintech Industry and Fintech Technologies Under Covid-19. ГРААЛЬ НАУКИ, (4), 68-70.

Krasnyuk, M., Tkalenko, A., \& Krasniuk, S. (2021). Results Of Analysis of Machine Learning Practice for Training Effective Model of Bankruptcy Forecasting in Emerging Markets.

Lim, S. H., Kim, D. J., Hur, Y., \& Park, K. (2019). An empirical study of the impacts of perceived security and knowledge on continuous intention to use mobile Fintech payment services. International Journal of Human-Computer Interaction, 35(10), 886- 898.

Lim, S. H., Kim, D. J., Hur, Y., \& Park, K. (2019). An empirical study of the impacts of perceived security and knowledge on continuous intention to use mobile Fintech payment services. International Journal of Human-Computer Interaction, 35(10), 886-898.

Rahim, N. F. A., Jaaffar, A. R., Sarkawi, M. N., \& binti Shamsuddin, J. (2021). Fintech and Commercial Banks Development in Malaysia: Continuous Intention to Use Fintech Services in IR 4.0 Environment. In Modeling Economic Growth in Contemporary Malaysia. Emerald Publishing Limited.

Ryu, H. S. (2018). What makes users willing or hesitant to use Fintech? the moderating effectof user type. Industrial Management \& Data Systems, 8(3), 541-569

Tasca, P., Aste, T., Pelizzon, L., \& Perony, N. (2016). Banking beyond banks and money. 
Cham: Springer International Publishing.

Zavolokina, L., Dolata, M., \& Schwabe, G. (2016, December). FinTech transformation: How ITenabled innovations shape the financial sector. In S. Feuerriegel \& D. Neumann (Eds.), Enterprise applications, markets and services in the finance industry (pp. 75- 88). Cham: Springer. FinanceCom 2016. 